Table 1. Tocilizumab therapy in ten cases of refractory arterio-BD

\begin{tabular}{|c|c|c|c|c|c|c|}
\hline Patient & $\begin{array}{l}\text { Age, } \\
\text { year }\end{array}$ & $\begin{array}{c}\text { Disease } \\
\text { duration, } \\
\text { months }\end{array}$ & $\begin{array}{c}\text { Clinical } \\
\text { features }\end{array}$ & $\begin{array}{l}\text { Arterial } \\
\text { lesions }\end{array}$ & $\begin{array}{l}\text { Previous } \\
\text { therapy }\end{array}$ & $\begin{array}{c}\text { Response } \\
\text { at week } \\
24\end{array}$ \\
\hline 1 & & & $\mathrm{O}, \mathrm{G}, \mathrm{P}$ & Stenosis of CA/ SMA/RA/ & Pred/CYC/ & \\
\hline 2 & 34 & 228 & S, I & $\begin{array}{l}\text { SCA, aortic valve prolapse } \\
\text { Dissecting aneurysm of AA }\end{array}$ & MMF & CR \\
\hline 3 & 20 & 24 & $\begin{array}{l}\mathrm{O}, \mathrm{S} \\
\mathrm{O}, \mathrm{G}, \mathrm{P}\end{array}$ & $\begin{array}{c}\text { (Debakey I) } \\
\text { thoracoabdominal aortic }\end{array}$ & $\begin{array}{l}\text { Pred/MMF } \\
\text { Pred/CYC/ }\end{array}$ & PR \\
\hline & 67 & 276 & S, A & aneurysm & TAC & CR \\
\hline $\begin{array}{l}4 \\
5\end{array}$ & 67 & 75 & $\mathrm{O}, \mathrm{S}, \mathrm{U}$ & $\begin{array}{l}\text { Stenosis of LAD/LCX/RCA } \\
\text { Abdominal and coronary }\end{array}$ & Pred /CYC & CR \\
\hline & 50 & 80 & $\mathrm{O}, \mathrm{G}, \mathrm{A}$ & aortic aneurysms & Pred /CYC & Relapse \\
\hline 6 & 48 & 26 & $\mathrm{O}, \mathrm{G}$ & Aortic insufficiency & Pred /CYC & PR \\
\hline 7 & 26 & 147 & $\mathrm{O}, \mathrm{P}, \mathrm{S}, \mathrm{V}$ & Iliac artery aneurysm & Pred /MMF & CR \\
\hline 8 & 49 & 466 & $\mathrm{O}, \mathrm{S}, \mathrm{V}$ & $\begin{array}{c}\text { Thoracoabdominal and coro- } \\
\text { nary aortic aneurysms }\end{array}$ & $\begin{array}{c}\text { Pred /CYC/ } \\
\text { AZA }\end{array}$ & CR \\
\hline $\begin{array}{l}9 \\
10\end{array}$ & 27 & 181 & $\mathrm{O}, \mathrm{P}, \mathrm{S}$ & $\begin{array}{l}\text { Pseudoaneurysm of CCA } \\
\text { Abdominal aneurysm, steno- }\end{array}$ & $\begin{array}{l}\text { Pred /CYC } \\
\text { Pred /CYC/ }\end{array}$ & PR \\
\hline & Male/55 & 354 & $O, P, S$ & sis of LAD/LCX/RCA & AZA & CR \\
\hline
\end{tabular}

*O: oral ulcer; G: genital ulcer; P: pathergy test; S: skin lesions; I: intestinal ulcer; A: arthritis; $\mathrm{U}$ : uveitis; V: venous thrombosis
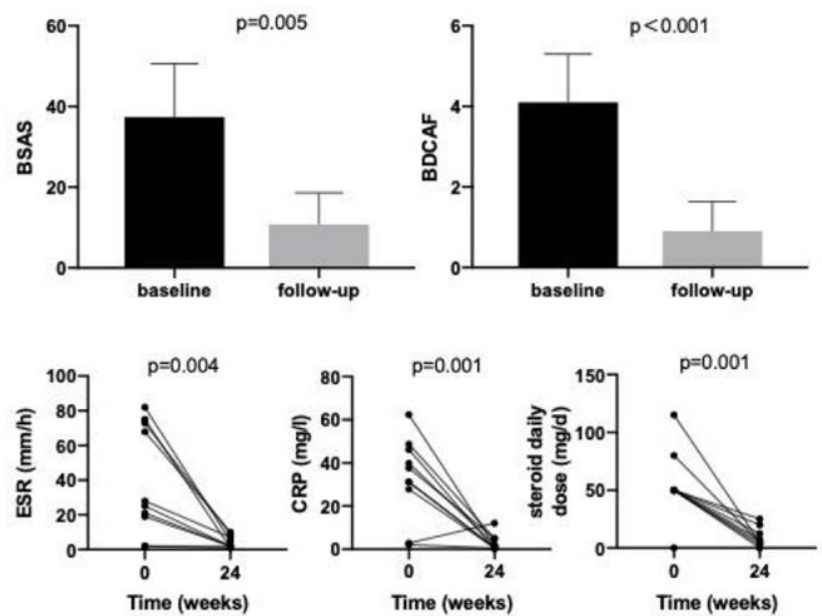

Figure 1. Changes from baseline in BSAS, BDCAF, ESR, CRP and steroid daily dose at 24 weeks

Disclosure of Interests: None declared

DOI: 10.1136/annrheumdis-2021-eular.2302

\section{AB0373 \\ PSYCHOMETRIC PROPERTIES OF OUTCOME MEASUREMENT INSTRUMENTS FOR LARGE VESSEL VASCULITIS: A SYSTEMATIC LITERATURE REVIEW}

G. Boleto ${ }^{1}$, A. Berti ${ }^{2}$, P. A. Merkel ${ }^{3}$, S. Aydin ${ }^{4}$, H. Direskeneli ${ }^{5}$, C. Dejaco ${ }^{6}$, L. Carmona 7 , S. Ramiro $8,9 .{ }^{1}$ Université de Paris, Hôpital Cochin, Rheumatology, Paris, France; ${ }^{2}$ Santa Chiara Regional Hospital and Department of Cellular, Computational and Integrative Biology (CIBIO), University of Trento, Rheumatology, Trento, Italy; ${ }^{3}$ Vasculitis Clinical Research Consortium; Hospital of the University of Pennsylvania, Rheumatology Division, Philadelphia, United States of America; ${ }^{4}$ University of Ottawa Faculty of Medicine, Rheumatology, Ottawa, Canada; ${ }^{5}$ Marmara University, Internal medicine, division of Rheumatology, Istanbul, Turkey; ${ }^{6}$ Medical University of Graz, Rheumatology, Graz, Austria; ${ }^{7}$ Instituto de Salud Musculoesquelética (InMusc), Rheumatology, Madrid, Spain; ${ }^{8}$ Leiden University Medical Center (LUMC), Rheumatology, Leiden, Netherlands; ${ }^{9}$ Zuyderland Medical Center, Rheumatology, Heerlen, Netherlands

Background: Giant cell arteritis (GCA) and Takayasu arteritis (TAK) are two forms of chronic progressive large-vessel vasculitis (LVV) of unknown etiology. In 2016, the OMERACT Vasculitis Working Group proposed the development of a Core Domain Set of outcome measures for LVV including organ and arterial function, fatigue, pain, biomarkers, and death (1). Understanding the psychometric properties of outcome measurement instruments is essential when selecting among instruments to use in research; a summary of such properties for measures of LVV has not been developed.
Objectives: To systematically review and summarize the psychometric properties of outcome measurement instruments used to measure the domains of the OMERACT core domain set for LVV.

Methods: A comprehensive search of several databases (Medline, EMBASE, Cochrane, among others) from inception to July 14,2020 was conducted. Articles were included if they covered psychometric properties of instruments used in LVV. Following the COSMIN and OMERACT frameworks, different psychometric properties (validity, inter- and intra-observer reliability, sensitivity to change, and feasibility) of outcome measurement instruments used in LVV (GCA and TAK) were assessed. Risk of bias was assessed according to the COSMIN checklist. Results: Among the 3534 articles identified, 15 studies focusing on the development or validation of psychometric properties on LVV met the predefined criteria. Two were development studies and 13 were validation studies. These studies provided information on 13 instruments: 5 instruments specific to TAK, 2 specific to systemic vasculitides, and 6 general, non-disease-specific instruments. No instruments specific to GCA were identified.

Of the main psychometric properties assessed in the included studies, $40 \%$ had a low, $47 \%$ had moderate, and $13 \%$ had high risk of bias. Construct validity was the property most frequently assessed (in $93 \%$ of the tools) (Figure 1).

In TAK, the Indian Takayasu Clinical Activity Score 2010 (ITAS2010) showed good consistency $(r=0.97)$, reliability (intra-observer, $I C C=0.60$; inter-observer ICC $=0.92$ ) and validity (correlation with Physician Global Assessment (PGA) $(r=0.73))$ for disease activity. Regarding disease damage, the Disease Extent Index-Takayasu (DEI-Tak) showed good validity (correlation with $\mathrm{NIH}$ score $94 \%$, $k=0.85)$. Non-specific vasculitis instruments such as the Vasculitis Damage Index (VDI) and the Birmingham Vasculitis Activity Score (BVAS) showed moderate validity in the assessment of disease damage in GCA (cumulative glucocorticoid dose and disease duration, $r=0.30$ and $r=0.29$ ) and TAK (cumulative glucocorticoid dose and disease duration, $r=0.29$ and $r=0.25$ ) in the former and disease activity in $\mathrm{GCA}$ in the later (PGA, $\mathrm{r}=0.50$ ).

Six non-vasculitis-specific patient-reported outcomes (PROs) instruments were identified, all showing low to moderate validity in GCA/TAK.

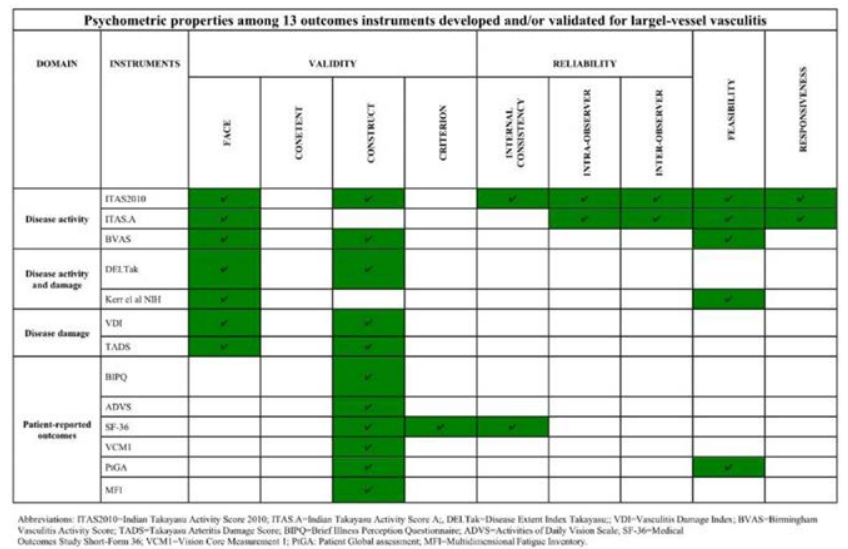

Conclusion: The psychometric properties of 13 outcome measures to study LVV covering the OMERACT domains of disease activity, damage, and patient-reported outcomes were assessed. ITAS2010, DEI-Tak, VDI, and BVAS were the instruments with better psychometric properties for disease activity and/or damage. Disease activity and/or damage instruments specific for GCA, and validated PROs for both GCA and TAK are needed. REFERENCES:

[1] Sreih GA, Alibaz-Oner F, Kermani TA, Aydin SZ, Cronholm PF, Davis T, et al. Development of a Core Set of Outcome Measures for Large-vessel Vasculitis: Report from OMERACT 2016 I The Journal of Rheumatology [Internet]. [cité 26 avr 2020]. Disponible sur: http://www.jrheum.org/content/44/12/1933. long

Disclosure of Interests: None declared

DOI: 10.1136/annrheumdis-2021-eular.2304

\section{AB0374 \\ CHARACTERISTICS OF A GIANT CELL ARTERITIS COHORT IN LATINOAMERICA}

T. Urrego Callejas ${ }^{1,2}$, D. Álvarez ${ }^{3}$, D. Jaramillo Arroyave ${ }^{4,5}$, A. L. VanegasGarcía $^{2,6}, C$. Muñoz ${ }^{2,3,5}$ on behalf of Grupo de Reumatología de la Universidad de Antioquia. ${ }^{1}$ Universidad de Antioquia, Facultad de Medicina, Medellín, Colombia; ${ }^{2}$ Universidad de Antioquia, Grupo de Reumatología Universidad de Antioquia, Medellín, Colombia; ${ }^{3}$ Hospital San Vicente Fundación, Internal Medicine, Rionegro, Colombia; ${ }^{4}$ Grupo de Epidemiología, Universidad CES, 
Epidemiología, Medellín, Colombia; ${ }^{5}$ IPS Universitaria Servicios de Salud Universidad de Antioquia, Rheumatology, Medellin, Colombia; ${ }^{6}$ Hospital San Vicente Fundación, Rheumatology, Medellín, Colombia

Background: Giant cell arteritis (GCA) is a large vessel vasculitis (LVV) that affects mostly the elderly (1). Temporal artery biopsy (TAB) has been defined as the gold standard, although this has come to question (3). EULAR guidelines recommended non-invasive imaging techniques such as the temporal artery Doppler ultrasound to aid in LVV diagnosis (2). The characterization of GCA in Latin American countries, and specifically in Colombia, is scarce.

Objectives: To perform a clinical, demographical, histopathological, and radiological characterization of

Colombian GCA patients.

Methods: Retrospective data from GCA patients at two teaching hospitals in Medellín, Colombia, was collected. A bioethics committee previously approved the research protocol. Inclusion criteria: diagnosis of GCA, based on clinical characteristics or imaging/biopsy findings. Exclusion criteria: HIV diagnosis, paraneoplastic large vessel vasculitis. Clinical, radiological, and histopathological variables were selected based on the clinicians' expertise and the 2018 EULAR recommendations for a core data set to support observational research and clinical care in giant cell arteritis (3). The data were analyzed in SPSS v22.0 (IBM, USA).

Results: Twenty-two patients were collected. Demographical and clinical characteristics are summarized in Table 1. Most patients were women (68.1\%), with a mean age of 71.8 years, mean duration of symptoms of 5.3 months. In the cranial form of the disease, the most common symptoms were headache and jaw claudication (95\% and $68 \%$ ). Six patients experienced visual loss: complete unilateral visual loss in two, partial unilateral in two, complete bilateral in one, and partial bilateral in one patient.

Sixteen patients $(72.7 \%)$ underwent TAB; the most common finding was mononuclear infiltrate and internal elastic fragmentation in $43.7 \%$ of the biopsies. Giant cells were observed in 6 biopsies (37.5\%). Doppler ultrasound was performed in 19 patients $(86.35 \%)$, finding intima-media thickening and the halo sign $t$ in 7 patients $(36.8 \%)$

Table 1. Demographical and clinical characteristics

\begin{tabular}{lc}
\hline Characteristic & $\mathbf{n = 2 2}$ \\
\hline Mean age (years SD) & $71.8(10.6)$ \\
Female sex $\mathrm{n}(\%)$ & $15(68.1 \%)$ \\
Mean symptoms duration (months \pm SD) & $5.3 \pm 6.8$ \\
Mestizo $\mathrm{n}(\%)$ & $20(90 \%)$ \\
Headache $\mathrm{n}(\%)$ & $21(95.4 \%)$ \\
Jaw claudication $\mathrm{n}(\%)$ & $15(68.1 \%)$ \\
Weight loss $\mathrm{n}(\%)$ & $13(59 \%)$ \\
Scalp sensitivity $\mathrm{n}(\%)$ & $11(50 \%)$ \\
Fever $\mathrm{n}(\%)$ & $8(36.3 \%)$ \\
Presence of polymyalgia rheumatica $\mathrm{n}(\%)$ & $7(31.8 \%)$ \\
Visual loss $\mathrm{n}(\%)$ & $6(27.2 \%)$ \\
Amaurosis fugax $\mathrm{n}(\%)$ & $1(4.5 \%)$ \\
Glucocorticoids n (\%) & $22(100 \%)$ \\
Pulse $\mathrm{n}(\%)$ & $8(36.3 \%)$ \\
Mean dose (mg \pm SD) & $47.1 \pm 16.7$ \\
Methotrexate $\mathrm{n}(\%)$ & $17(77.7 \%)$ \\
Azathioprine $\mathrm{n}(\%)$ & $2(9 \%)$ \\
Tocilizumab $\mathrm{n}(\%)$ & $1(4.5 \%)$ \\
&
\end{tabular}

Conclusion: In this GCA cohort, the main phenotype was cranial GCA, with $95 \%$ of the patients presenting with headache. The most common imaging study performed was Doppler ultrasound of temporal arteries, with intima-media thickening and halo sign being the most common findings. The mainstay of treatment was glucocorticoids with methotrexate as a sparing agent. To our knowledge, this study is the first to perform a specific characterization of GCA patients in the Colombian population, and it can represent the foundation of further research for these patients.

REFERENCES:

[1] Lazarewicz K, Watson P. Giant cell arteritis. BMJ. 2019 May 30;365:I1964.

[2] Dejaco C, Ramiro S, Duftner C, Besson FL, Bley TA, Blockmans D, et al. EULAR recommendations for the use of imaging in large vessel vasculitis in clinical practice. Ann Rheum Dis. 2018 May;77(5):636-43.

[3] Ehlers L, Askling J, Bijlsma HWJ, Cid MC, Cutolo M, Dasgupta B, et al. 2018 EULAR recommendations for a core data set to support observational research and clinical care in giant cell arteritis. Ann Rheum Dis. 2019;78(9):1160-6.

Disclosure of Interests: None declared

DOI: 10.1136/annrheumdis-2021-eular.2436

\section{AB0375 EXTERNAL VALIDATION OF THE GIANT CELL ARTERITIS PROBABILITY SCORE IN THE NETHERLANDS}

L. M. Neuman ${ }^{1}$, M. Van Nieuwland ${ }^{1}$, M. Vermeer ${ }^{2}$, D. Boumans ${ }^{1}$, E. Colin ${ }^{1}$, C. Alves ${ }^{1}{ }^{1}$ Hospital Group Twente, Rheumatology and Clinical Immunology, Almelo, Netherlands; ${ }^{2}$ Hospital Group Twente, ZGT Academy, Almelo, Netherlands

Background: Severe complications of giant cell arteritis (GCA), such as blindness and ischemic stroke, can be prevented by timely treatment. This requires early and accurate diagnosis. In 2019, Laskou et al. developed a clinical GCA probability score (GCAPS) that allows physicians to assess the probability of GCA at initial assessment. The GCAPS is suitable for easy implementation in daily practice. It has a high sensitivity $(95.7 \%)$ and specificity $(86.7 \%)$ at a cut-off value of 9.5 as proposed by Laskou et al.

Objectives: The aim of this study was to externally validate the GCAPS in a general hospital.

Methods: A retrospective cohort of patients with suspected GCA between January $1^{\text {st }} 2017$ and October $1^{\text {st }} 2019$ at Ziekenhuisgroep Twente (the Netherlands) was used. As the parameter extra-cranial artery abnormality was not available in our cohort, a modified version of the GCAPS was used (m-GCAPS). The m-GCAPS was compared to clinical diagnosis of a rheumatologist after six months in accordance with Laskou et al. The validity of the m-GCAPS was assessed by plotting a receiver operating characteristic (ROC) curve and assessing sensitivity and specificity for multiple cut-off values. For practical purposes, risk stratifications as proposed by Sebastian et al. (2020) were applied to our data (low-risk <9; intermediate-risk 9-12; high-risk >12).

Results: In our cohort, 40 GCA patients and 95 controls (suspected of GCA) had complete records and were therefore used for analysis. In the patient group, $29(72.5 \%)$ were female and mean (SD) age was $73.3(1.6)$. The area under the ROC curve (AUC) was $0.83(95 \% \mathrm{Cl} 0.75-0.91)$. At our optimal cut-off value of 10.5 , sensitivity was $80.0 \%$ and specificity was $75.8 \%$. In total, 5 patients and 45 controls were stratified as low, 7 patients and 35 controls as intermediate and 28 patients and 15 controls as high-risk.

Conclusion: The m-GCAPS showed good discrimination in our cohort. Risk stratification of patients looks promising, although cut-off values by Sebastian et al. might need optimization based on population and modification to the GCAPS. Colour Doppler ultrasound is recommended by EULAR as the first-choice diagnostic test to confirm GCA in case of high pre-test probability and exclude GCA for low pre-test probability. The (m-)GCAPS may aid in quantification of this pretest probability.

REFERENCES:

[1] Laskou F, Coath F, Mackie SL et al. A probability score to aid the diagnosis of suspected giant cell arteritis. Clin Exp Rheumatol. 2019;37 Suppl 1(2):104-8.

[2] Sebastian A, Tomelleri A, Kayani A et al. Probability-based algorithm using ultrasound and additional tests for suspected GCA in a fast-track clinic. RMD Open. 2020 Sep 1;6(3):e001297.

[3] Dejaco C, Ramiro S, Duftner $C$ et al. EULAR recommendations for the use of imaging in large vessel vasculitis in clinical practice. Ann Rheum Dis. 2018 May 1;77(5):636 LP - 643 .

Table 1. Cut-off values of the m-GCAPS stratified into risk categories as proposed by Sebastian et al. Sensitivity, specificity, positive predictive value (PPV) and negative predictive value (NPV) and the number of patients scoring above or below the cut-off values are described (optimal cut-off value in blue). The total number of patients with a score within low- (red), intermediate- (orange) and high- (green) risk categories are depicted.

\begin{tabular}{|c|c|c|c|c|c|c|c|c|c|c|}
\hline & $\begin{array}{c}\mathrm{GCA}+(\mathrm{N}) \\
\mathrm{N}=40\end{array}$ & $\begin{array}{c}\text { GCA- (N) } \\
\mathrm{N}=95\end{array}$ & $\begin{array}{r}\mathrm{Sc} \\
\mathrm{m}-\mathrm{GC}\end{array}$ & $\begin{array}{l}\text { ore } \\
\text { CAPS }\end{array}$ & $\begin{array}{c}\text { GCA+ } \\
\text { (N) }\end{array}$ & $\begin{array}{l}\text { GCA- } \\
\text { (N) }\end{array}$ & $\begin{array}{c}\text { Sens. } \\
(\%)\end{array}$ & $\begin{array}{c}\text { Spec. } \\
(\%)\end{array}$ & $\begin{array}{l}\text { PPV } \\
(\%)\end{array}$ & $\begin{array}{l}\text { NPV } \\
\text { (\%) }\end{array}$ \\
\hline \multirow[t]{2}{*}{ Low-risk <9 } & $5(12.5 \%)$ & 45 (47.4\%) & 5.5 & $\begin{array}{l}<5.5 \\
>5.5\end{array}$ & $\begin{array}{c}0 \\
40\end{array}$ & $\begin{array}{l}14 \\
81\end{array}$ & 100 & 14.7 & 33.1 & 100 \\
\hline & & & 8.5 & $\begin{array}{l}<8.5 \\
>8.5\end{array}$ & $\begin{array}{c}5 \\
35\end{array}$ & $\begin{array}{l}45 \\
50\end{array}$ & 87.5 & 47.4 & 41.2 & 90 \\
\hline $\begin{array}{l}\text { Intermediate- } \\
\text { risk }\end{array}$ & 7 (17.5\%) & 35 (36.8\%) & 9.5 & $\begin{array}{l}<9.5 \\
>9.5\end{array}$ & $\begin{array}{c}8 \\
32\end{array}$ & $\begin{array}{l}56 \\
39\end{array}$ & 80 & 58.9 & 45.1 & 87.5 \\
\hline \multirow[t]{2}{*}{$9-12$} & & & 10.5 & $\begin{array}{l}<10.5 \\
>10.5\end{array}$ & $\begin{array}{c}8 \\
32\end{array}$ & $\begin{array}{l}72 \\
23\end{array}$ & 80 & 75.8 & 58.2 & 90 \\
\hline & & & 11.5 & $\begin{array}{l}<11.5 \\
>11.5\end{array}$ & $\begin{array}{l}10 \\
30\end{array}$ & $\begin{array}{l}74 \\
21\end{array}$ & 75 & 77.9 & 58.8 & 88.1 \\
\hline $\begin{array}{l}\text { High-risk } \\
>9\end{array}$ & 28 (70.0\%) & $15(15.8 \%)$ & 12.5 & $\begin{array}{l}<12.5 \\
>12.5\end{array}$ & $\begin{array}{l}12 \\
28\end{array}$ & $\begin{array}{l}80 \\
15\end{array}$ & 70 & 84.2 & 65.1 & 87 \\
\hline \multirow{2}{*}{$>9$} & & & 14.5 & $\begin{array}{l}<14.5 \\
>14.5\end{array}$ & $\begin{array}{l}18 \\
22\end{array}$ & $\begin{array}{c}89 \\
6\end{array}$ & 55 & 93.7 & 78.6 & 83.2 \\
\hline & & & 19.5 & $\begin{array}{l}<19.5 \\
>19.5\end{array}$ & $\begin{array}{c}37 \\
3\end{array}$ & $\begin{array}{c}95 \\
0\end{array}$ & 7.5 & 100 & 100 & 72 \\
\hline
\end{tabular}

